OPEN ACCESS

Citation: Marco Cedeño-Fonseca, Orlando O. Ortíz, Alejandro Zuluaga, Mario Jiménez-Segura, Thomas B. Croat (2020)Anew orange-fruited species of Monstera (Araceae: Monsteroideae) from Panama. Webbia. Journal of Plant Taxonomy and Geography 75(2): 251-262. doi: 10.36253/jopt-9680

Received: September 5, 2020

Accepted: September 10, 2020

Published: November 18, 2020

Copyright: @2020Marco Cedeño-Fonseca, Orlando O. Ortíz, Alejandro Zuluaga, Mario Jiménez-Segura, Thomas B. Croat. This is an open access, peerreviewed article published by Firenze University Press (http://www.fupress. com/webbia) and distributed under the terms of the Creative Commons Attribution License, which permits unrestricted use, distribution, and reproduction in any medium, provided the original author and source are credited.

Data Availability Statement: All relevant data are within the paper and its Supporting Information files.

Competing Interests: The Author(s) declare(s) no conflict of interest.

Editor: Sin Yeng Wong

\section{A new orange-fruited species of Monstera (Araceae: Monsteroideae) from Panama}

\author{
Marco Cedeño-Fonseca ${ }^{1, *}$, Orlando O. Ortíz ${ }^{2}$, Alejandro Zuluaga 3 , \\ Mario Jiménez-Segura ${ }^{4}$, Thomas B. Croat ${ }^{5}$ \\ ${ }^{1}$ Herbario Luis Fournier Origgi (USJ), Universidad de Costa Rica, San José, Costa Rica \\ ${ }^{2}$ Herbario PMA \& Departamento de Botánica, Universidad de Panamá, Estafeta Univer- \\ sitaria, Panama City, Republic of Panamá \\ ${ }^{3}$ Departamento de Biología, Universidad del Valle, Calle 13, \#100-00, Cali, Colombia \\ ${ }^{4}$ Macaw Recovery Network, Escazú, Costa Rica, 10203 \\ ${ }^{5}$ Missouri Botanical Garden, 4344 Shaw Blvd., St. Louis, MO 63110, USA \\ ${ }^{\star}$ Corresponding author. E-mail: marcovf.09@gmail.com
}

Abstract. Monstera alcirana, endemic to Panamá, is described and illustrated using a color plate based on photographs of the vegetative and reproductive structures of living material. This species is the fourth of the very small species of Monstera in Central America. It is morphologically similar to M. obliqua, M. minima and M. gambensis but differs by has short internodes, thickly coriaceous blade and peduncle longer than the length of the leaf.

Keywords: Aroids, Central America, Monstera obliqua, Panamanian flora.

\section{INTRODUCTION}

Monstera, a climbing aroid genus best known for its often perforated leaf blades, remains rather poorly understood in the Neotropics as a whole, though progress has recently been made for Mexico and Central America (Grayum 2003; Cedeño-Fonseca 2019; Cedeño-Fonseca et al. 2018, 2020a, 2020 b), including the recent publication of several new species in the region: Monstera anomala Zuluaga \& Croat, M. integrifolia Zuluaga \& Croat, M. limitaris M. Cedeño, M. guzmanjacobiae Díaz Jim., M. Cedeño, Zuluaga \& Aguilar-Rodr., M. croatii M. Cedeño \& A. Hay and M. gambensis M. Cedeño \& M.A. Blanco (Cedeño-Fonseca et al. 2018; Zuluaga \& Cameron 2018; Cedeño et al. 2020b; Díaz-Jiménez et al. 2020). Costa Rica and Panama are the centre of diversity of the genus, principally in the Talamanca mountain range below $2300 \mathrm{~m}$ elevation (Madison 1977; Cedeño-Fonseca et al. 2020a), and particularly the Caribbean slope.

Hitherto, Monstera obliqua Miq., was the only known species in Costa Rica and Panama with an orange fruiting spadix (Madison 1977; Grayum 2003; Cedeño-Fonseca 2019). This species is most common from the south of Panama, mainly in the Chocó biogeographic region, and throughout the 
Amazon basin, where orange spadix is more frequent in the genus (Madison 1977). Other species with orange fruiting spadix are Monstera praetermissa E.G. Gonç. \& Temponi, endemic to Bahia, Brazil (Gonçalves \& Temponi 2004), and Monstera xanthospatha Madison endemic to the Cordillera Occidental and the Cordillera Central of the Andes in Colombia (Madison 1977). Monstera obliqua itself appears to be a large and variable species complex with orange fruiting spadices. Most probably some populations of $M$. obliqua in the Amazonian basin might be resolved as separate species with further research.

Here we describe and illustrate a new species endemic from Panama with an orange fruiting spadix, and we include an extensive documentation of the populations of M. obliqua in Costa Rica and Panama.

\section{TAXONOMIC TREATMENT}

Monstera alcirana Croat, M. Cedeño, Zuluaga \& O. Ortiz sp. nov.

Type: Panamá. Coclé: along ridge of Cerro Gaital, N slopes of mountains near La Mesa, $\mathrm{N}$ of El Valle; 28 April 1982, $8^{\circ} 40^{\prime} \mathrm{N}, 80^{\circ} 7^{\prime} \mathrm{W}, 800-900 \mathrm{~m}$, Knapp \& Dressler 4880 (holotype, MO; isotypes, K, PMA, US).

\section{Diagnosis}

Monstera alcirana is recognised by its small, entire, thickly coriaceous leaves lacking fenestrations, petioles with deciduous sheath, primary lateral veins arising from the midrib at $35-45^{\circ}$, peduncle longer than the leaf, spathe creamy yellow on both surfaces, and the orange spadix when the fruits are ripe.

\section{Description}

Nomadic vine with appressed-climbing habit. Seedlings: foliose. Juvenile plants: stems smooth, terete, dark-green; internodes $1.5-2.5 \mathrm{~cm}$ long, $4-6 \mathrm{~mm}$ diam.; petiole conspicuous, light green, smooth, $4-9 \mathrm{~cm}$ long, sheathing to the base of the blade; petiole sheath slightly persistent or completely deciduous; blades oblong-elliptic to lanceolate, attenuate at the base, coriaceous, 3-6 $\times$ 3-4 cm, not appressed to the phorophyte; fenestrations absent. Adult plants: stems dark green, smooth, terete or slightly flattened; internodes $0.5-3 \mathrm{~cm}$ long, 5-10 $\mathrm{mm}$ diam.; anchor roots black and corky, with black root hairs; feeder roots black and corky, with black root hairs; petiole light green, smooth, $5-15 \mathrm{~cm}$ long, sheathing to the base of the geniculum; petiolar sheath deciduous; geniculum bulky, $0.5-1 \mathrm{~cm}$ long; blades nar- row, lanceolate, oblong-elliptic or ovate, attenuate at the base, obtuse or short-acuminate at apex, thickly coriaceous, drying yellowish, $7.5-25 \times 3-10 \mathrm{~cm}, 2.4-3.5$ times longer than wide, with the base slightly decurrent on the geniculum; midrib sunken adaxially, convex abaxially; primary lateral veins 4-7 per side, departing from midrib at $35-45^{\circ}$, strongly sunken adaxially, raised abaxially; tertiary veins inconspicuous; collective veins not visible; fenestrations absent; margins entire. Inflorescences on ascending stems; peduncle smooth, $10-38 \mathrm{~cm}$ long, 2-4 mm diam.; spathe light-green during development, cream on both surfaces at the anthesis; spadix white during development, cream at the anthesis, 3-5.2 cm long, $0.7-1 \mathrm{~cm}$ diam.; flowers 3-4 mm long; stamens with laminar filaments, $1.5-4 \mathrm{~mm}$ long; anthers $0.5-1$ $\mathrm{mm}$ long; ovary quadrangular and ribbed, $1.5-2.5 \times 1.5-$ $2 \mathrm{~mm}$; style hexagonal, $1-2 \times 2-2.5 \mathrm{~mm}$; stigma linear; basal sterile flowers $1.5-3 \mathrm{~mm}$ long; berries with orangegreen stylar cap, greenish during development; pulp white; seeds green or black, spherical, 2-4 mm long.

\section{Etymology}

The species is named in honor of Alcira Pérez de Gómez a Venezuelan botanist from Barquisimeto who did her Master's thesis under the direction of Tom Croat at St. Louis University in St. Louis.

\section{Distribution and habitat}

Monstera alcirana is endemic to Panama to the Comarca Guna Yala and Provinces of Coclé, Panamá, Colón and Veraguas, at 350-1000 m, in Tropical wet forest and Premontane rain forest life zones (Holdridge 1967).

\section{Conservation status}

Monstera alcirana occurs in nine localities of which four are in protected areas (Chagres National Park, Cerro Gaital Natural Monument, General de División Omar Torrijos Herrera National Park and Santa Fe National Park). The principal threat to this species is the habitat loss due to urban expansion and extensive livestock activities, which were observed mainly in those locations devoid of protection. We calculate an Extent of Occurrence of $9236 \mathrm{~km}^{2}$ and an Area of Occupancy of $80 \mathrm{~km}^{2}$, therefore, we suggest considering M. alcirana as a vulnerable species [VU, Blab(i,ii,iii,iv)].

\section{Phenology}

Flowering has been recorded in January-April, July, November, and fruiting in January-May, and July. 


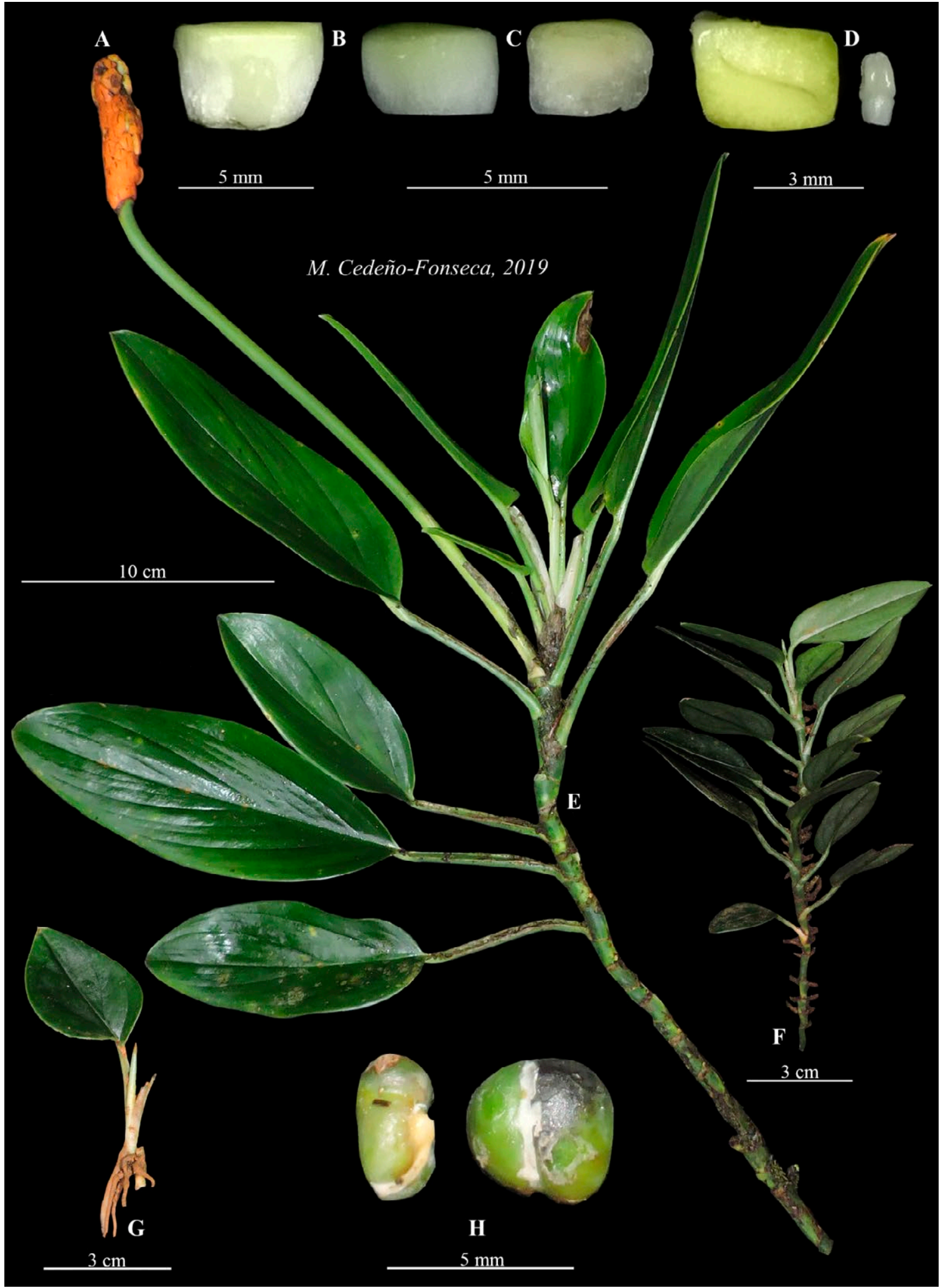

Figure 1. Monstera alcirana sp. nov. A. Infructescence. B. Fertile flower. C. Sterile flower in lateral view (left) and in longitudinal section (right). D. Stylar plate, top view (left), and individual stamen (right). E. Adult plant. F. Juvenile plant. G. Seedling. H. Seeds. Images by M. Cedeño-Fonseca. 


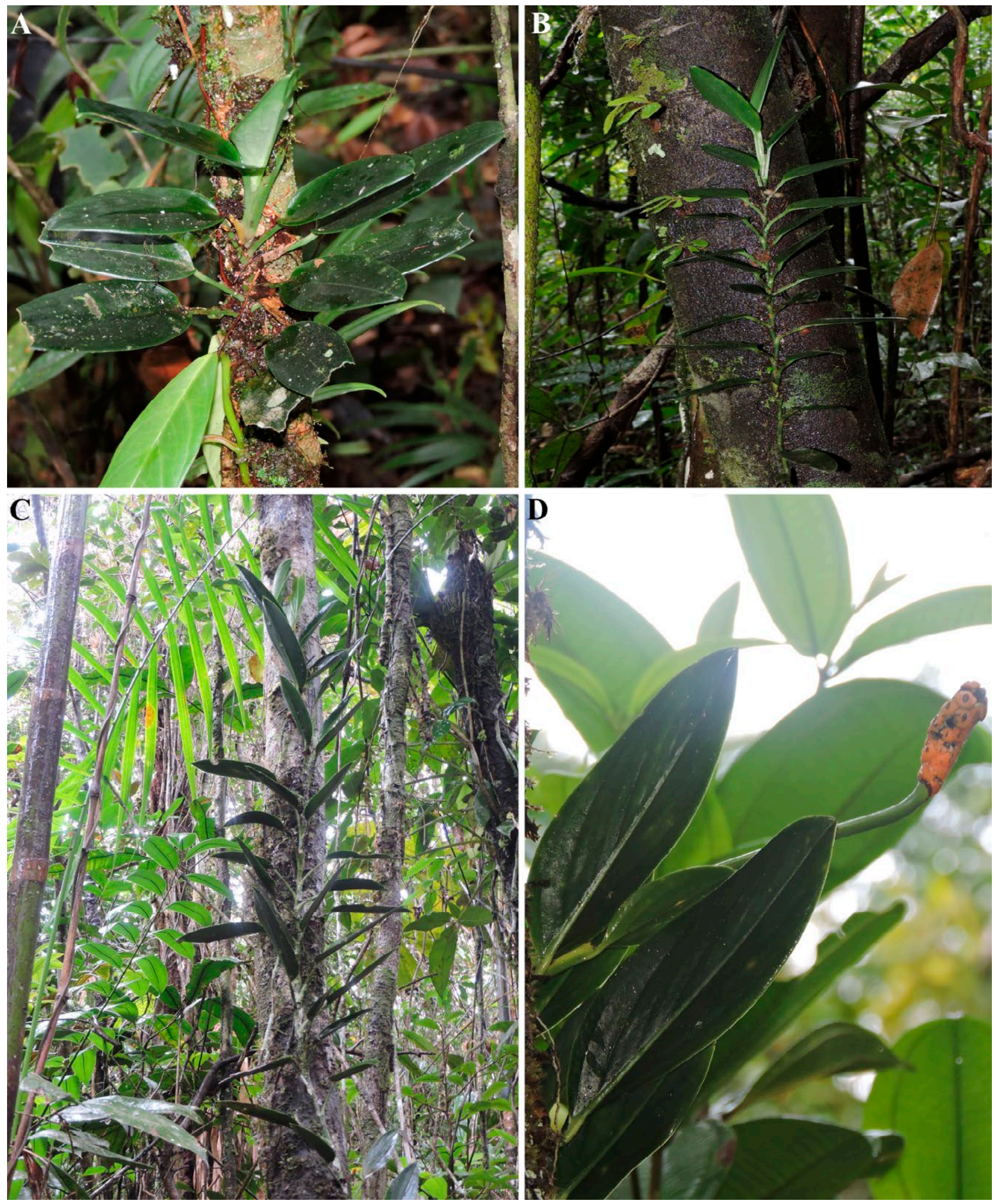

Figure 2. Monstera alcirana sp. nov. A. Juvenile plant. B. Pre-adult plant. C. Adult plant without inflorescence. D. Adult plant with infructescence. Images by M. Cedeño-Fonseca. 
Notes

The new species is a member of sect. Monstera (sensu Madison, 1977), and is unusual in the genus in having leaves that are somewhat like Stenospermation, and indeed the species was long confused with that genus (Gómez, 1983).

The species superficially resembles Stenospermation, it is impossible to confuse $M$. alcirana with any other species of Monstera. It is similar to M. obliqua in having the same color of the spathe and spadix, but it differs because $M$. alcirana has short internodes $0.5-3 \mathrm{~cm}$ long (vs. 2-10 cm long), thickly coriaceous blade (vs. a thinly coriaceous blade), peduncle 10-38 cm long (vs. 10-17 cm long), and the juvenile with small leaf blade 3-6 $\times 3-4$ $\mathrm{cm}$ (vs. 7-13 $\times 2-4 \mathrm{~cm}$ ). The pre-adult and adult plants of $M$. alcirana are very similar to the juvenile plant of M. standleyana G.S. Bunting.

The other species that can be confused M. alcirana is M. minima Madison, but M. minima is only known from the type locality in the Comarca Guna Yala (formerly San Blas), Panama, and from Colombia. The key differences are that $M$. alcirana has an orange fruiting spadix (vs. an apparently creamy fruiting spadix), and a thickly coriaceous leaf blade, $7.5-25 \times 3-10 \mathrm{~cm}$ (vs. a thinly coriaceous blade $9-14 \times 2.0-4.0 \mathrm{~cm}$ ), obtuse or short-acuminate at apex (vs. long-acuminate at the apex). Monstera alcirana is the fourth diminutive species of Monstera in Central America, together with $M$. minima Madison, M. obliqua Miq., and the recently published species M. gambensis M.Cedeño \& M.A.Blanco (Cedeño-Fonseca et al. 2020b). Monstera alcirana differs from the latter species in having a smooth petiole (vs. rough petiole), the petiole sheath deciduous (vs. persistent and involute), and the fruiting spadix orange when ripe (vs. yellow when ripe).

\section{Additional specimens studied (paratypes):}

PANAMA: Coclé, La Mesa above El Valle; in forest on both sides of junction with road to Cerro Pilon, ca. 800 m, 21 Jul 1974, T.B. Croat 25390 (MO). Along road between Llano Grande and Coclesito ( $\mathrm{N}$ of Pintada), $4 \mathrm{mi}$. N of Llano Grande, $600 \mathrm{~m}, 28$ Jan 1980, T. Antonio 3561 (MO). $27 \mathrm{~km} \mathrm{~N}$ of Penonome on road to Coclesito in forest reserve at Continental Divide, ca. 300 m, 20 Feb 1978, B. Hammel 1635 (MO). Vicinity el Valle de Antón, at forested flat area near Finca Macarenita at La Mesa, $08^{\circ} 36^{\prime} \mathrm{N}, 80^{\circ} 07^{\prime} \mathrm{W}, 800 \mathrm{~m}, 6$ Jul 1994, T.B. Croat \& G.H. Zhu 76665A (MO). Parque Nacional General de División Omar Torrijos Herrera, Caño Sucio, camino hacia el Alto Tífe, bosque húmedo

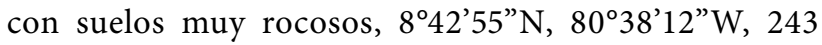
m, 18 Jul 2013, O. Ortiz et al. 1416 (MO, PMA). Colón:
East Santa Rita Ridge, 11 January 1968, M.D. Correa \& R.L. Dressler 595 (MO). Near Agua Clara rainfall station, Santa Rita Ridge, 9 9 $20^{\prime} \mathrm{N}, 79^{\circ} 48^{\prime} \mathrm{W}, 23$ Apr 1970, R.B. Foster 1752 (PMA). Along ridge of Cerro Gaital, $\mathrm{N}$ slopes of mountains near La Mesa, $\mathrm{N}$ of El Valle, Premontane rainforest, $08^{\circ} 38^{\prime} 00^{\prime \prime} \mathrm{N}, 80^{\circ} 08^{\prime} 30^{\prime \prime} \mathrm{W}, 800-$ 900 m, 28 Apr 1982, S. Knapp \& R. J. Schmalzel 4880 (MO). Flotation Molly, 851'12”N, 80³8'18”W, $139 \mathrm{~m}$, 21 May 2014, S. Castillo 402 (PMA). Distrito de Donoso, área de Concesión Minera Panamá, Pipeline Road, $8^{\circ} 53^{\prime} 46^{\prime \prime} \mathrm{N}, 80^{\circ} 38^{\prime} 50^{\prime \prime} \mathrm{W}, 127 \mathrm{~m}, 6$ May 2013, O. Ortiz et al. 1310 (MO, PMA). Panamá, Between 6-12 km north of El Llano on Cartí road, forest and roadside, $09^{\circ} 15^{\prime} 32^{\prime \prime} \mathrm{N}, 078^{\circ} 57^{\prime} 42^{\prime \prime} \mathrm{W}-09^{\circ} 16^{\prime} 32^{\prime \prime} \mathrm{N}, 078^{\circ} 55^{\prime} 49^{\prime \prime} \mathrm{W}$, 365 m, 13 Jan 1978, B.E. Hammel 889 (MO). Cerro Jefe, ca. 1000 m, J.D. Dwyer 9480 (MO). El Llano-Cartí Road, $17.5 \mathrm{~km}$ from Inter-American Highway, wet forest, $09^{\circ} 17^{\prime} 45^{\prime \prime} \mathrm{N}, 78^{\circ} 55^{\prime} 59^{\prime \prime} \mathrm{W}, 350 \mathrm{~m}, 14 \mathrm{Feb} 1975$, S.A. Mori et al. 4605 (MO). Altos de Pacora, northwest of Cerro Jefe, $09^{\circ} 16^{\prime} 30^{\prime \prime} \mathrm{N}, 79^{\circ} 18^{\prime} 50^{\prime \prime} \mathrm{W}, 650-750 \mathrm{~m}, 8 \mathrm{Nov}$ 1979, T. Antonio 2502 (MO). 16-18 km from Interamerican Highway on the El Llano-Cartí Road, $09^{\circ} 17^{\prime} 50^{\prime \prime} \mathrm{N}$, 7856’03"W, $400 \mathrm{~m}, 28 \mathrm{Mar} 1974$, E. L. Tyson \& M. H. Nee 7342 (MO). 8.2 miles from the Pan-American Highway on the El Lano-Cartí Road, $09^{\circ} 14^{\prime} \mathrm{N}, 79^{\circ} 00^{\prime \prime} \mathrm{W}, 6 \mathrm{Jul}$ 1982, S. Knapp 5917 (MO). Beyond Goofy Lake along road to Cerro Jefe, $9^{\circ} 14^{\prime} \mathrm{N}, 79^{\circ} 21^{\prime} \mathrm{W}, 4$ Jan 1968 , M.D. Correa et al. 567 (MO, PMA). Campo Tres, 3 miles NE of Altos de Pacora, 500-800 m, 10 Mar 1973, R.L. Liesner 523 (MO, PMA). Road to Cartí (San Blas), 15.5 kn north of El Llano, $09^{\circ} 21^{\prime} 30^{\prime \prime} \mathrm{N}, 78^{\circ} 58^{\prime} 00^{\prime \prime} \mathrm{W}$, ca. 400 m, 13 Feb 1973, P. Busey 366 (MO). La Eneida, región of Cerro Jefe, $9^{\circ} 14^{\prime} \mathrm{N}, 79^{\circ} 21^{\prime} \mathrm{W}, 650 \mathrm{~m}, 15$ Jan 1973, R.L. Dressler 4253 (PMA). El Llano-Cartí Rd. km. 17.4, Tropical wet forest, $9^{\circ} 19^{\prime} \mathrm{N}, 78^{\circ} 55^{\prime} \mathrm{W}, 350 \mathrm{~m}, 1 \mathrm{Jul} 1985, G$. de Nevers 5922 (MO, PMA). Altos de Cerro Azul, sendero el Cantar, $500 \mathrm{~m}, 16$ Sept 2015, O. Ortiz et al. 2515 (MO, PMA). Veraguas, Santa Fe, Río Piedra, bosque secundario maduro, camino cerca del río, $8^{\circ} 44^{\prime} 06^{\prime \prime} \mathrm{N}$, $80^{\circ} 46^{\prime} 21^{\prime \prime} \mathrm{W}, 370 \mathrm{~m}, 16$ Dec 2013, A. Morris \& L. Martínez 2062 (PMA). Santa Fe, Parque Nacional Santa Fe, área del Río Veraguas, bosque achaparrado, trocha sobre filo de un cerro, dosel con una altura aproximada de $25 \mathrm{~m}$,

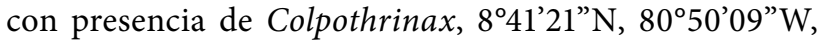
539 m, 8 Feb 2014, L. Martínez et al. 1672 (PMA).

\section{Monstera obliqua Miq., Linnaea 18: 79. 1844}

Type: Surinam, Vredenburger-Zandrits, October 1842, Focke 719 (holotype, U; photos: BH, SEL!). 
(=) Monstera falcifolia Engler, Bot. Jahrb. 37: 117. 1905. Type: BRAZIL. Amazonas, Jurua Miry, July 1901, Ule 5622 (holotype, B; photos: BH, GH, US; isotypes, K, L!, MG; photo: $\mathrm{BH}$ ).

(=) Monstera fendleri Engler, Bot. Jahrb. 37: 117. 1905. Type: TRINIDAD. 1877-1880, Fendler 736 (holotype, K!; isotypes: NY, P).

(=) Monstera sagotiana Engler, Bot. Jahrb. 37: 117. 1905. Type: FRENCH GUIANA, Karouany, Sagot 609 (holotype, BM; photo: $\mathrm{BH}$ ).

(=) Monstera snethlagei Krause, Notizbl. Bot. Gart. Berlin-Dahlem 9: 272. 1925. Type: BRAZIL, Maranhão, Jury-assu, Mta. de Allegria, Ketterpflanze im Igapowald, gelb, Hüllblatt ebenfalls gelb, 14 November 1923, Snethlage 327 (holotype, B; photos: $\mathrm{BH}, \mathrm{GH}, \mathrm{US}$ ).

\section{Description}

Nomadic vine with appressed-climbing habit. Seedlings: foliose. Juvenile plants: stems smooth, dark green; internodes $3-5 \mathrm{~cm}$ long, $2-5 \mathrm{~mm}$ diam.; petiole conspicuous, dark green, smooth 5-11 cm long, sheathing to the base of the geniculum; petiole sheath deciduous; blades lanceolate, truncate at the base, acuminate at apex, sub-coriaceous, 7-13 $\times 2-4 \mathrm{~cm}$, not appressed to the phorophyte; fenestrations absent. Adult plants: stems smooth, light to dark green; internodes $2-10 \mathrm{~cm}$ long, 3-5 mm diam.; cataphylls light-green, deciduous but leaving dry fragments on peduncles; anchor roots black; feeder roots black; petiole light green, smooth, 5-18 cm long, sheathing to the geniculum, petiole sheath deciduous; geniculum smooth, 3-5 mm long; blades lanceolate to narrowly elliptical, cuneate at the base, acuminate at apex, membranous to sub-coriaceous, drying blackish, reddish, light brown or greyish, 12-23 $\times 3-10 \mathrm{~cm}$, not decurrent on geniculum; midrib ribbed adaxially, convex abaxially; primary lateral veins $4-8$, obscure adaxially, prominent abaxially, departing midrib at $35-50^{\circ}$; tertiary veins inconspicuous; collective veins not visible; fenestrations absent or scarcely developed (in Central America); margins entire. INFLORESCENCES on ascending stems, 1-3 simultaneously at flowering time, arranged in the axils of the leaves or cataphylls; peduncle smooth, 10-17 cm long, 5-6 mm diam.; spathe acuminate, light-green during development, yellow externally and white internally at anthesis, the margins towards the apex involute, deciduous at the end of the anthesis, up to $4 \mathrm{~cm}$ longer than the spadix; spadix with green style margins and white at the medial part during development, cream at anthesis, $3-5 \times 0.5-1$ $\mathrm{cm}$; flowers 4-7 $\mathrm{mm}$ long; stamens with laminar filaments, 1-2 mm long; anthers 1-2 mm long; ovary square and ribbed, $1.5-2 \times 1.5-2 \mathrm{~mm}$; style square or hexagonal, $1.5-2 \times 2.5-3 \mathrm{~mm}$; stigma linear; basal sterile flowers scarce or absent; berries with a moss-green stylar cap during development, mature stylar cap orange; pulp white; seeds black, 3-5 mm long.

\section{Distribution and ecology}

Monstera obliqua ranges from Costa Rica to Bolivia, Venezuela, the Guianas, Brazil, and Trinidad \& Tobago. In Costa Rica it grows at $0-100 \mathrm{~m}$ elevation, in Tropical wet forest life zones, but in Panama it grows at 0-1410 m, in Tropical moist forest, Tropical lower montane wet forest and Montane moist forest life zones (Holdridge 1967).

\section{Phenology}

In Costa Rica and Panama, flowering has been recorded in July and November, and fruiting in January, March, July and November.

Notes

The species is a member of sect. Monstera (sensu Madison, 1977), characterized by its small elliptic-lanceolate, inequilateral blades which have entire margins, usually lack perforations, its inflorescences with peduncles that are as long as or longer than petioles (but not the whole leaf) and by its dark orange, small fruiting spadix.

Monstera obliqua in Costa Rica is only known from the southeast Caribbean watershed. It is not common, and possible to find only in primary and secondary forests, at 0-100 m. Most populations have leaf blades without perforations: only the populations in the region of Sixaola have fenestrate blades. This species is the only Monstera with orange ripe fruit in Costa Rica, (Figure 3).

However, the situation for Panama is different: $M$. obliqua is very common along to the Caribbean slope, at 0-1410 m, growing in Tropical wet forest, Tropical moist forest, Tropical lower montane wet forest, and Montane moist forest life zones (Holdridge 1967). The most common morphotype is one with the leaf blades without perforations similar to the plant from Costa Rica, but the only difference is the much wider altitudinal distribution. (Figure 4-5). Monstera obliqua in Panama grows in rocks where it can develop to the adult phase and producing inflorescences. (Figure 4A-B). Some plants from the Cerro Azul in Panamá have coriaceous leaf blades, with the indistinct primary lateral veins in both surfaces and prominently thick geniculum and peduncles (Figure 4F-G, 5).

Monstera obliqua has never been recorded for Costa Rica and Panama with perforated and membranaceous 


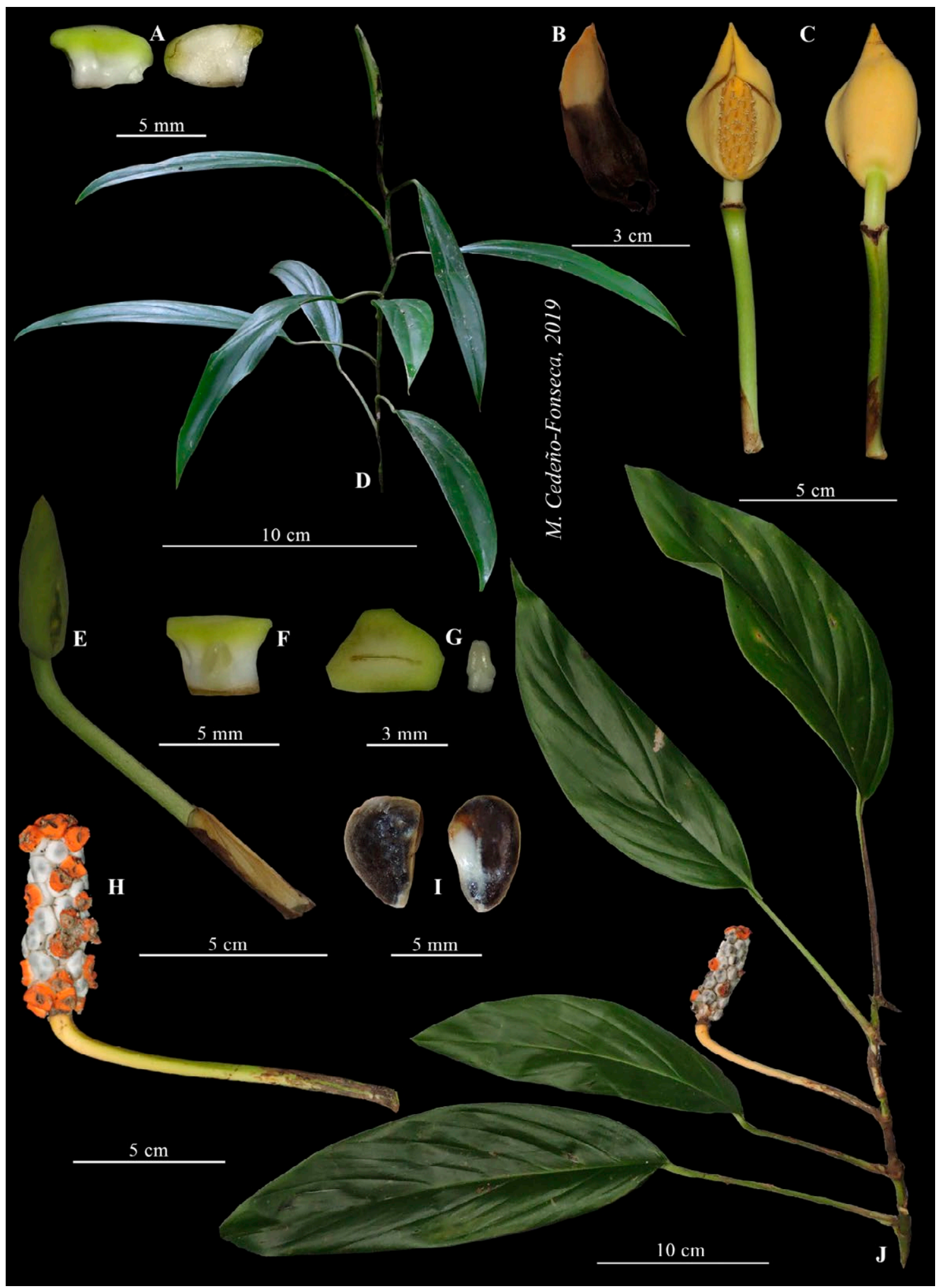

Figure 3. Monstera obliqua from Costa Rica. A. Sterile flower in lateral view (left) and in longitudinal section (right). B. Spathe anomaly. C. Front and back views of open inflorescence. D. Juvenile plant. E. Developing inflorescence. F. Fertile flower. G. Stylar cap, top view (left), and individual stamen (right). H. Mature infructescence, stylar cap detached toward the apical part. I. Seeds. J. Adult plant. Images by M. Cedeño-Fonseca. 

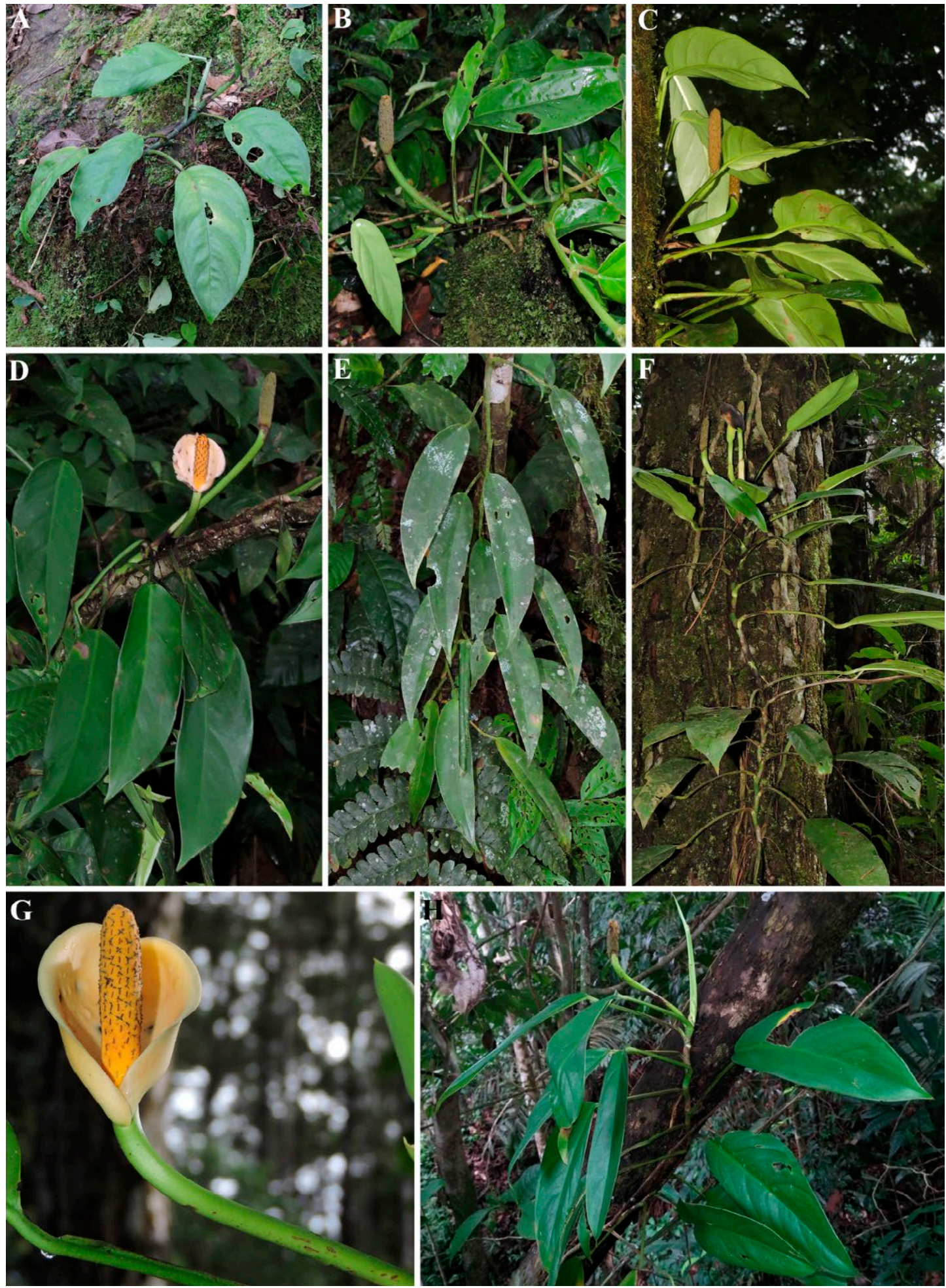

Figure 4. Different morphotypes of Monstera obliqua from Panama. A. Plant in adult phase with infructescence growing on rocks in the Caribbean in Bocas del Toro. B. Plant in adult phase with infructescence growing on rocks in the Pacific in Santa Fe. C. Adult plant growing $3 \mathrm{~m}$ above the ground on trees in Santa Fe. D. Adult plant with a white spathe growing $1 \mathrm{~m}$ above the ground on a shrub in the Cope. E. Juvenile individual growing in the Cope. F. Adult plant with inflorescence and infructescence growing on trees in Cerro Azul. G. Inflorescence with creamy spathe in Cerro Azul. H. Adult plant with infructescence growing $2 \mathrm{~m}$ above the ground in Santa Rita. Images by M. Cedeño-Fonseca. 


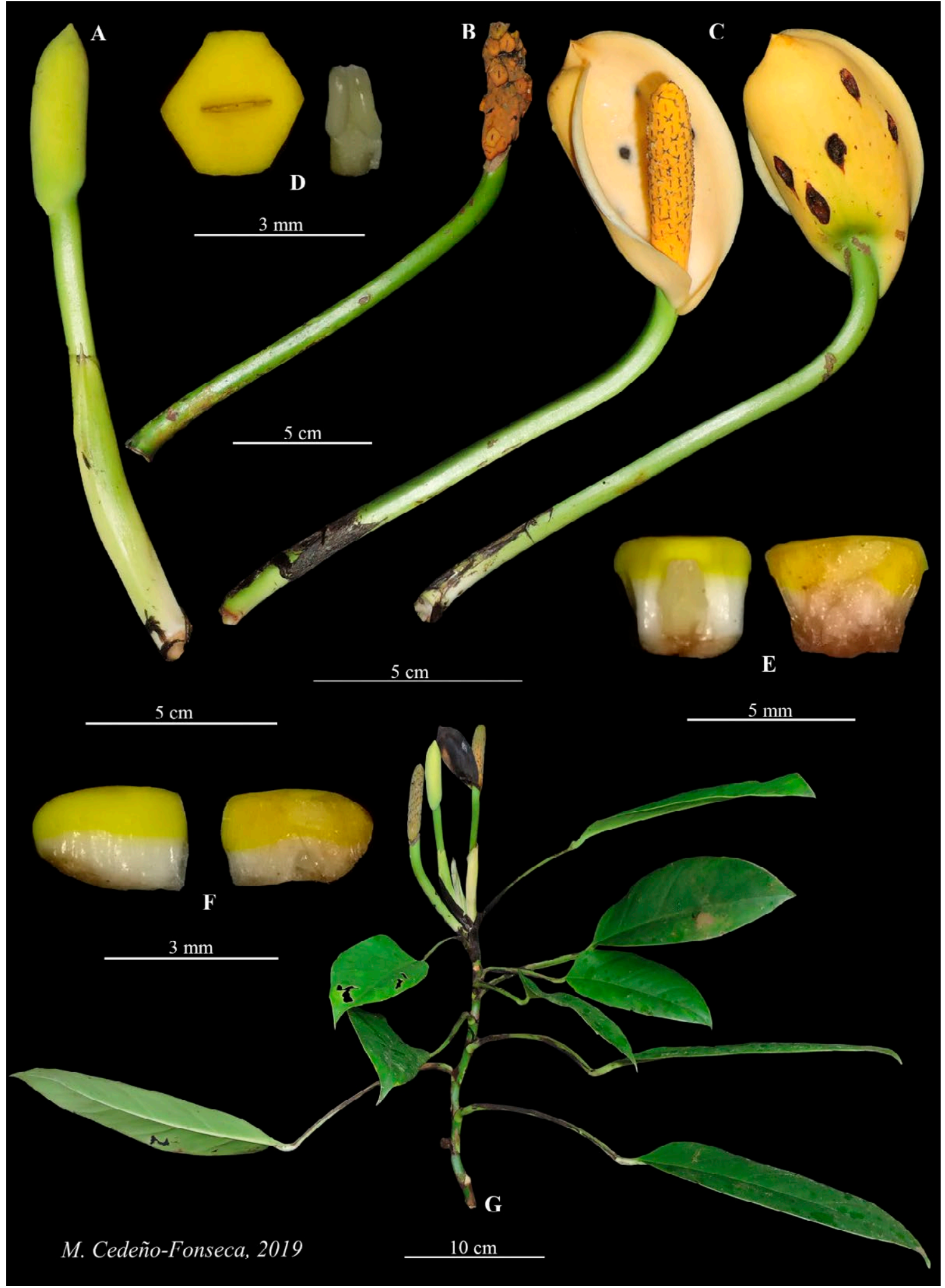

Figure 5. Monstera obliqua from Panamá, Cerro Azul. A. Developing inflorescence. B. Mature infructescence. C. Front and back views of open inflorescence. D. Stylar cap, top view (left), and individual stamen (right). E. Fertile flower in lateral view (left) and in longitudinal section (right). F. Sterile flower in lateral view (left) and in longitudinal section (right). G. Adult plant. Images by M. Cedeño-Fonseca. 
leaf blades. This characteristic is present solely in one morphotype occurring throughout the Amazon basin and which may be a different species since (the type of M. obliqua is not of this morphotype). Madison (1977) speculated that the entire leaf morphotype from Panama (which also occurs in Costa Rica) was probably driven by a limited immigrant line from South America with a consequent decline in genetic variability.

\section{Additional specimens studied:}

COSTA RICA: Limón, Talamanca, Sixaola, San Miguel de Sixaola, Finca-albergue de ASACODE, $9^{\circ} 34^{\prime} 10^{\prime \prime} \mathrm{N} 82^{\circ} 39^{\prime} 20^{\prime \prime} \mathrm{W}, 35 \mathrm{~m}, 28$ July 1994, (Fr.), J. Sánchez et al. 340 (CR). Talamanca, Bratsi, Suretka, Bosques cercanos al sitio de exploración petrolera, 9³5’20”N 8253'50”'W, 200 m, 19 July 1995, (Fl., Fr.), A. Cascante et al. 551 (CR). Talamanca, Cahuita, Between Bri Bri and Sixaola, NW of Paraíso, Disturbed forest, $9^{\circ} 39^{\prime} 0^{\prime \prime} \mathrm{N} 82^{\circ} 40^{\prime} 0^{\prime \prime} \mathrm{W}, 50$ m, 5 July 1983, (Fr.), K. Barringer et al. 3489 (CR, MO). Talamanca, Sixaola, Hills between headwaters of Quebrada Mata de Limón and upper branches of Quebrada Tigre, and lowland forest of Quebrada Tigre drainage, Finca Anai, (Sixaola region), 9³4'0”N 8240'0”'W, 28 m, 18 November 1984, (Fl., Fr.), M. Grayum et al. 4458 (CR, MO). Talamanca, Sixaola, Headwaters of quebrada Mata de Limón, westernmost fork, Finca Anai, (Sixaola region), 9 $34^{\prime} 0^{\prime \prime} \mathrm{N} 82^{\circ} 39^{\prime} 0^{\prime \prime} \mathrm{W}$, 23 m, 17 November 1984, (Fr.), M. Grayum et al. 4439 (CR, MO). Talamanca, Cahuita, Gandoca, El Llano entre Fila Manzanillo y Río Creek, Atrás de la playa, 9³7'0"N 8241'0"W, 80 m, 27 March 1995, (Fr.), G. Herrera \& E. Sandoval 7600 (CR). Limón, Valle La Estrella, Fila

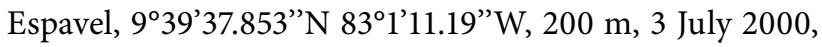
(Fr.), L. Acosta 2117 (CR). Talamanca, Sixaola, Sendero Cerillo, 9³6'38.821'N 82³7'24.9'”, 1 m, 3 March 1999, (Fr.), U. Chavarría 1920 (CR). Talamanca, Sixaola, San Miguel, senderos en la ruta a Manzanillo, 9 $34^{\prime} 30^{\prime \prime} \mathrm{N}$ 8240'0”W, 30 m, 16 January 1997, (Fr.), J. González 1582 (CR). Camino entre Fila Dimat y Río Uren, 22 October 1985, (Fr.), L. Gómez 23765 (MO). 10 miles S of Punta

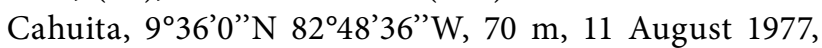
(Infert.), T.B Croat 43199A (MO). Talamanca, Bribri, Proyecto ARA, 9 ${ }^{\circ} 37^{\prime} 43^{\prime \prime} \mathrm{N} 82^{\circ} 40^{\prime} 31^{\prime \prime} \mathrm{W}, 4 \mathrm{~m}, 30$ September 2018, (Fl., Fr.), M. Cedeño et al. 1481 (USJ). Talaman-

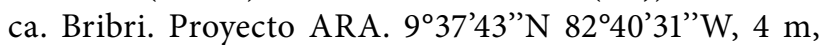
30 September 2018, (Fr.), M. Cedeño et al. 1482 (USJ). PANAMA: Bocas del Toro, Above Chiriquí Grande on side road $10 \mathrm{mi}$ from continental divide; on trail off pipeline trace, $8^{\circ} 55^{\prime} \mathrm{N}, 82^{\circ} 10^{\prime} \mathrm{W}, 300 \mathrm{~m}, 28$ May 1988, G. McPherson 12569 (MO). Hill just south of Chiriquí Grande; at end of pipeline access road $2 \mathrm{mi} \mathrm{N}$ of 2 nd large bridge $\mathrm{N}$ (10 mi.) of cont. divide, $8^{\circ} 54^{\prime} \mathrm{N}, 82^{\circ} 10^{\prime} \mathrm{W}$,
350-500 m, 10 Mar 1986, Hammel et al. 14743 (MO). Vicinity of Chiriquí Lagoon, 8 Oct 1940, Wedel 1091 (MO). Milla, 7.5, 26 July 1971, T.B Croat \& Porter 16277 (MO). Chiriquí, Chiriquí Grande-Fortuna, along Continental Divide from road branching $\mathrm{N}$ off main FortunaChiriquí Grande Highway near Continental Divide, 1.1 mi from main highway, $8^{\circ} 44^{\prime} \mathrm{N}, 82^{\circ} 17^{\prime} \mathrm{W}, 1200 \mathrm{~m}, 11$ Mar 1985, T.B Croat \& M. Grayum 60347 (MO). Coclé: Cerro Pilon near El Valle, 700-900 m, 700-900 m, 10 June 1967, Duke 12155 (MO). Between Cerro Pilon and El Valle, 700-900 m, 15 Aug 1967, Duke 13993 (MO). El Valle, 1000 m, 24 Dec 1972, Gentry 6893 (MO). El Valle; end of road leading to Turstico Hotel, 11 May 1977, Folsom 3111 (MO). Trail between the Río Blanco and the Continental Divide $\mathrm{N}$ of El Cope and El Potroso sawmill, 400-1700 ft, 14 Dec 1980, Sytsma et al. 2580 (MO). Vicinity of El Valle, 600-1000 m, 8 Dec 1938, Allen 1227 (MO). Mountains beyond La Pintada, 400-600 m, 16 Feb 1935, Hunter \& Allen 544 (MO). Cerro Pilón, 2000$2700 \mathrm{ft}, 28$ Mar 1969, Dwyer et al. 4565 (MO). Continental divide $\mathrm{N}$ of Penonome on road to Coclesito, $1600 \mathrm{ft}$, 25-26 July 1978, Hammel 4039 (MO). Foot of Cerro Pilón, above El Valle de Antón. Rain forest, $2000 \mathrm{ft}, 28$ Mar 1969, Porter et al, 4612 (MO). El Valle de Anton, La Mesa, 1000 m, 1 Apr 1973, Helen et al. 3011 (MO). El Valle site, on the end of the trail from the end of the road to the site, 24 Apr 1968, Kirkbride 1082 (MO). Continental divide, $4 \mathrm{mi}$ past Llano Grande on road to Cascajal, NW of Penónome, 500 m, 9 Apr 1981, Sytsma 3878 (MO). Road from Penonomé to Coclecito, $9 \mathrm{~km} \mathrm{~N}$ of Llano Grande, tributary on Río Caseaja, 11 Oct 1978, D’Arcy \& Hammel 12282 (MO). Colón: Santa Rita Ridge, Santa Rita (Arriba)-Cerro Azul, 09 $20^{\prime} 21^{\prime \prime} \mathrm{N}$, 7946’47'W, 200-260 m, 23 July 1990, Grayum \& Evans 9922 (MO). Santa Rita Ridge Road, $6.5 \mathrm{mi}$ E of BoydRoosevelt Hwy, $09^{\circ} 21^{\prime} 15^{\prime \prime} \mathrm{N}, 79^{\circ} 44^{\prime} 00^{\prime \prime} \mathrm{W}, 370 \mathrm{~m}, 16$ July 1994, Croat \& Zhu 76941 (GB, MO, SAR). 25-26 kms from Transisthmica Hwy on Santa Rita Ridge, $09^{\circ} 26^{\prime} \mathrm{N}$, 079³7’W, 500 m, 21 Oct 1981, Knapp et al. 1733 (MO). Santa Rita Ridge, E of Agua Clara rain gauge, 4 March 1973, Kennedy 2753 (MO). Santa Rita Ridge. In forest on Tassell's property, 8 Nov 1974, Mori \& Kallunki 3026 (MO). Santa Rita lumber road, $8.7 \mathrm{~km}$ E of Transisthimian Highway, 15 June 1977, Folsom 3690 (MO). Santa Rita Ridge Road, $7.8 \mathrm{~km}$ from the Boyd-Roosevelt Hwy., ca 25 km W of Colón., 23 Aug 1975, Mori \& Dressler 7907 (MO). Trail S of Río Guanche, on ridge to Cerro Pan de Azúcar, 200 m, 20 Sept 1974, Mori \& Kallunki 2031 (MO). $9 \mathrm{~km} \mathrm{~W}$ of Llano Grande just S of Cascajal, $800 \mathrm{ft}, 11$ Oct 1978, Hammel \& D'Arcy 5099 (MO). Darién: Vicinity Cerro Pirre, along trail from base camp to Rancho Frio on slopes of Cerro Pirre, $07^{\circ} 58^{\prime} \mathrm{N}$, 
77²3’W, 200-450 m, 27 July 1994, Croat \& Zhu 77130 (MO). Parque Nacional Darién, subiendo por la trocha limitrofe desde Casa Vieja hacia Cerro Sapo, $07^{\circ} 58^{\prime} \mathrm{N}$, $78^{\circ} 23^{\prime} \mathrm{W}, 500-800$ m, 25 May 1991, Herrera et al. 1000 (MO). Parque Nacional Darién, Serranía de Cerro Sapo, por la trocha limitrofe del PND entre Casa Vieja y Cerro Sapo, $07^{\circ} 58^{\prime} \mathrm{N}, 78^{\circ} 23^{\prime} \mathrm{W}, 20-400$ m, 24 Nov 1990, Herrera \& Polanco 742 (MO). Parque Nacional del Darién. Slopes of Cerro Mali; head waters of $S$ branch of Río Pucuro; ca. $22 \mathrm{~km}$ E of Pucuro., $08^{\circ} 04^{\prime} 30^{\prime \prime} \mathrm{N}$, 77¹4’00”W, 1300-1400 m, 21 Oct 1987, Cuadros et al. 3912 (MO). Parque Nacional del Darién. Ridge between Río Topalisa \& Río Pucuro ca. $13 \mathrm{~km}$ E of Pucuro; Quebrada Pobre to Mi Casita, $8^{\circ} 03^{\prime} \mathrm{N}, 77^{\circ} 20^{\prime} \mathrm{W}, 450-600 \mathrm{~m}$, 14 Oct 1987, Nevers et al. 8316 (MO). Parque Nacional del Darién Ridge between N \& S Branches of Río Pucuro; in forest $\mathrm{N}$ of old village of Tacarcuna; ca. $18 \mathrm{~km} \mathrm{E}$ of Pucuro, $8^{\circ} 05^{\prime} \mathrm{N}, 77^{\circ} 16^{\prime} \mathrm{W}, 600-800 \mathrm{~m}, 24$ Oct 1987 , Hammel et al. 16486 (MO). Cerro Tacarcuna Expedition. South slope of Cerro Tacarcuna above Río Pucuro base camp, 700-1000 m, 25 January 1975, Gentry \& Mori 13899 (MO, PMA). Cerro Tacarcuna Expedition. Trail from Pico Mali to old Tacarcuna village on Río Tacarcuna, premontane wet forest, 700 m, 7 Feb 1975, Gentry \& Mori 14181 (MO). Cativo Swamp, Río Chucunaque, ca. 1/2 hr below Morti, 18-31 May 1967, Duke 11749 (MO). $10 \mathrm{~km}$ NE of Jaqué, headwaters of Río Pavarandó, 1400 ft, 30 Jan 1981, Sytsma \& D'Arcy 3352 (MO). $10 \mathrm{~km} \mathrm{NE}$ of Jaqué, ridge between Río Tabuelita and Río Pavarandó., 1400-1600ft, 1 Feb 1981, D’Arcy \&. Sytsma 14551 (MO). Near Jacque at Enseñada del Guayabo, Apr 1980, Garwood 1024 (MO). Cerro Mali: Cerro Tacarcuna Expedition. Trail from Tacarcuna village on Río Tacarcuna to Cerro Mali, 800-1300 m, 16 Jan 1975, Gentry \& Mori 13601 (MO). Parque Nacional Darién: S of Garachine near Pacific coast above Casa Vieja along boundary trail, W flank of Serranía Sapo, $7^{\circ} 58^{\prime} \mathrm{N}, 78^{\circ} 23^{\prime} \mathrm{W}, 150$ 300 m, 22 May 1991, Hensold 1083 (MO, PMA). Punta Guayabo Grande: N of Punta Guayabo Grande, trail to ridge top, 200-600 ft, 21 Apr 1980, Antonio \& Hahn 4346 (MO, PMA). Panamá, Along trail to Cerro Brewster from Río Pacora Valley, $9^{\circ} 20^{\prime} \mathrm{N}, 7^{\circ} 15^{\prime} \mathrm{W}$. Forested slopes c. $650 \mathrm{~m}, 9^{\circ} 20^{\prime} \mathrm{N}, 7^{\circ} 15^{\prime} \mathrm{W}, 650 \mathrm{~m}, 21 \mathrm{Nov} 1985$, G. McPherson 7558 (MO). $1 \mathrm{mi} \mathrm{N}$ Cerro Azul, $2300 \mathrm{ft}, 27$ May 1966, Tyson \& Blum 4088 (FSU, MO); El LlanoCarti Road, $10 \mathrm{~km}$ from Interamerican Hwy., 5 Oct 1974, Mori \& Kallunki 2326 (MO). Campo Tres, $3 \mathrm{mi} \mathrm{NE}$ of Altos de Pacora, 500-800 m, 10 Mar 1973, Liesner 578 (MO). Cerro Azul, 23 June 1972, T.B Croat 17304 (MO). El Llano-Cartí Road, $09^{\circ} 16^{\prime} \mathrm{N}, 078^{\circ} 58^{\prime} \mathrm{W}, 1000 \mathrm{ft}, 6 \mathrm{Sep}$ 1980, Sytsma 996 (MO). El Llano-Carti road, $12 \mathrm{~km} \mathrm{~N}$ of Pan. Am. Hwy at El Llano, 400 m, 11 Mar 1974, Nee
10450 (MO). Cerro Azul, 24 Mar 1969, Porter et al. 4070 (MO). Porter et al. 4098 (MO). 2-3 mi S of Goofy Lake, road to Cerro Jefe, 2000-2200 ft, $10 \mathrm{Dec} 1966$, Lewis et al. 264 (MO). Near foot of Loma Larga, east of Cerro Azul (Goofy Lake), 5 Apr 1973, Dressler 4319 (MO, PMA). vicinity of Finca Neptuno, $3.5 \mathrm{~km}$ NE of Lago Cerro Azul on road to Cerro Jefe., 600-800 m, 11 May 1974, Nee 11524 (MO). El Llano-Carti Road, $9.6 \mathrm{~km}$ from Inter-American Highway, 350 m, 26 May 1975, Mori \& Kallunki 6402 (MO). Comarca Guna Yala, Nusagandí, 30 May 1993, Marrianne 25 (MO). Trail from mouth of Río Irgandí to a tributary of Río Cartí Senni. Two hours through second growth, one hour through forest. $9^{\circ} 25^{\prime} \mathrm{N}, 78^{\circ} 51^{\prime} \mathrm{W}$., $9^{\circ} 25^{\prime} \mathrm{N}, 78^{\circ} 51^{\prime} \mathrm{W}, 20$ Dec. 1985 , Nevers \& Herrera $6580(\mathrm{MO})$. Cangandi, $9^{\circ} 24^{\prime} \mathrm{N}, 7^{\circ} 24^{\prime} \mathrm{W}$. $9^{\circ} 24^{\prime} \mathrm{N}, 79^{\circ} 24^{\prime} \mathrm{W}, 30 \mathrm{~m}, 10 \mathrm{Feb} 1986$, Nevers \& Herrera 7041 (MO). Cangandi, hills around village. Assoc: Cespedizia macrophylla, $9^{\circ} 24^{\prime} \mathrm{N}, 79^{\circ} 24^{\prime} \mathrm{W}$., $9^{\circ} 24^{\prime} \mathrm{N}, 79^{\circ} 24^{\prime} \mathrm{W}$, 50 m, 13 Dec. 1985, Nevers et al. 6487 (MO, PMA). El Llano-Cartí Road, $19.1 \mathrm{~km}$ from Interamerican Hwy; elev. $350 \mathrm{~m} .9^{\circ} 19^{\prime} \mathrm{N}, 78^{\circ} 55^{\prime} \mathrm{W}, 9^{\circ} 19^{\prime} \mathrm{N}, 78^{\circ} 55^{\prime} \mathrm{W}, 350 \mathrm{~m}, 4$ Mar 1985, Nevers et al. 4951 (MO). Campamanto Nusgandi, en ELC a $19.1 \mathrm{~km}$ de la vía Panamaericana, Sendero Wedar Igar, $9^{\circ} 11^{\prime} \mathrm{N}, 78^{\circ} 15^{\prime} \mathrm{W}, 200-350 \mathrm{~m}, 31 \mathrm{Oct}$ 1992, Herrera et al. 1265 (MO, PMA). Nusagandí; El Llano-Cartí Road, $9 \mathrm{mi} \mathrm{N}$ of main highway; Nergan Igar (Nergan Trail), $09^{\circ} 20^{\prime} \mathrm{N}, 79^{\circ} 00^{\prime} \mathrm{W}, 350 \mathrm{~m}, 2$ July 1994, Croat \& Zhu 76563 (CM, MO). Trail east of CangandiMandinga airport road, 2-5 mi S of Mandinga airport. 27 Oct 1967, Duke 14813 (MO). Cerro Habú, trail from Río Sidro, primary wet forest, $09^{\circ} 23^{\prime} \mathrm{N}, 078^{\circ} 49^{\prime} \mathrm{W}, 800-$ $1400 \mathrm{ft}, 18$ Dec 1980, Sytsma et al. 2635 (MO). On trail to inland village of Armila, 3 to $8 \mathrm{~km} \mathrm{SW}$ of Puerto Obaldía, 21 June 1975, Mori et al. 6798 (MO). Puerto Obaldía and trail to Colombian Frontier, 0-500 m, 28 Apr 1980, D’Arcy 13624 (MO). 3-4 hours up Río Mulatupu, 17 Aug 1967, Kirkbride 229 (MO). El Llano-Cartí road, $10.5 \mathrm{mi}$ from Interamerican Hwy., $09^{\circ} 18^{\prime} \mathrm{N}$, 0795 'W, 550 m, 14 Mar 1985, Croat 60487 (MO). Nusagandi: Sendero Wedar, $9^{\circ} 18^{\prime} \mathrm{N}, 78^{\circ} 58^{\prime} \mathrm{W}, 300-400 \mathrm{~m}, 19$ July 1986, McDonagh et al. 174 (BM). Veraguas, Slopes of Cerro Tute, along trail from between first and second creeks $\mathrm{N}$ of height above Alto de Piedra; forest, $08^{\circ} 30^{\prime} \mathrm{N}$, $81^{\circ} 07^{\prime} \mathrm{W}, 600-750 \mathrm{~m}, 21$ March 1987, McPherson 10730 (MO). Trail on ridge to summit of Cerro Tuté, Cordillera de Tute. $1 \mathrm{~km}$ past Escuela Agricola Altos de Piedra, just $\mathrm{W}$ of Santa Fe, upper montane and elfin forest, $08^{\circ} 36^{\prime} \mathrm{N}$, 0810' W, 1250-1410 m, 15 December 1981, Knapp \& Sytsma 2532 (MO). Vicinity of Escuela Agricola Alto Piedra near Santa Fe, $0.3 \mathrm{mi}$ beyond the fork in the road near the agricultural school toward Atlantic coast, along trail to top of Cerro Tute, 1050-1150 m, 29 November 
1979, Croat 48887 (MO, PMA). Carribbean slope above Río Primero Brazo $5 \mathrm{mi} \mathrm{NW}$ of Santa Fe, 700-1200 m, 18-19 Mar 1973, Liesner 801 (MO). Along trail to summit of Cerro Tute, ca. $3 \mathrm{~km}$ above Escuela Agricultura Alto Piedra near Santa Fé, 2600-2800 ft, 4 Jan 1981, Sytsma \& Antonio 2987 (MO). Vicinity of Escuela Agricultura Alto Piedra, near Santa Fé along trail to top of Cerro Tute, $2800 \mathrm{ft}, 3$ Apr 1980, Antonio 3978 (MO). Along road from Santa Fé to Río Calovebora 0.6 mile beyond Escuela Agricola Alto Piedra, 735 m, 4 Apr 1976, Croat \& Folsom 34133 (MO). $0.6 \mathrm{mi}$ beyond Escuela Agricola Alto Piedra, 730 m, 4 Apr 1976, Croat \& Folsom 34000 (MO). Caribbean slope above Río Primero Brazo $5 \mathrm{mi} \mathrm{NW}$ of Santa Fé, 700-1200 m, 18-19 Mar 1973, Croat 23146 (MO). Road beyond Escuela Agricola Alto Piedra, above Santa Fé, Atlantic watershed., 800-1000 m, 1 Jan 1975, James et al. 4566 (DUKE); $1 \mathrm{~km}$ past Agricultural School, forested slope to the rear. Road from Santa Fe, 1000-1200 m, 5 Feb 1977, Folsom \& Collins 1610 (MO).

\section{ACKNOWLEDGMENTS}

Marco Cedeño-Fonseca thanks the Organization for Tropical Studies for a Glaxo-Wellcome research grant and the Rexford Daubenmire fellowship, which supported fieldwork for the project "Taxonomy of the genus Monstera (Alismatales: Araceae) for Costa Rica", and an Alwyn H. Gentry Fellowship from the Missouri Botanical Garden and a Mini-ARTS Fellowship from the Society of Systematic Biologists, which allowed him to study herbarium material at the Missouri Botanical Garden, the Marie Selby Botanical Gardens, and the New York Botanical Garden. Michael Mittermeier, Cristina Goettsch Mittermeier, and Caroline Sparks also helped in raising funds for travel through a Gofundme.com campaign. Orlando O. Ortiz thanks Jerry Harrison, Ramón da Pena and the following institutions for sponsoring this research through either field or herbarium work: University of Panama, University of Florence (Italy), Missouri Botanical Garden and M.W.H. Panama.

\section{REFERENCES}

Cedeño-Fonseca MV. 2019. Revisión taxonómica del género Monstera (Araceae) en Costa Rica. Unpublished M.Sc. thesis, Programa de Posgrado en Biología, Sistema de Estudios de Posgrado, Universidad de Costa Rica, San José, Costa Rica.

Cedeño-Fonseca M, Hay A, Grayum MH \&82 Blanco MA. 2020a. Two new endemic species of Monstera
(Araceae: Monsteroideae: Monstereae) from Golfito in southern Costa Rica. Webbia. 75(1): 123-132.

Cedeño-Fonseca M, Karremans AP, Ortíz OO. 2018. Monstera limitaris (Araceae), a new species from the border between Costa Rica and Panama. Phytotaxa. 376: 37-42.

Cedeño-Fonseca, M., O.O. Ortiz, A. Zuluaga, and M.A. Blanco. 2020b. New records of Araceae for Costa Rica and Panama. Phytoneuron. 39: 1-7.

Gonçalves E.G. \& L.G. Temponi. 2004. A New Monstera (Araceae: Monsteroideae) from Brazil Author. Brittonia. 56 (1): 72-74.

Gómez, AP. 1983. A revision of Stenospermation (Araceae) in Central America. Master's thesis, Saint Louis University, St. Louis, Missouri.

Grayum M.H. 2003. Araceae. Pp. 59-200, in B.E. Hammel, M.H. Grayum, C. Herrera, and N. Zamora (eds.). Manual de Plantas de Costa Rica. Volumen II: Gimnospermas y Monocotiledóneas (AgavaceaeMusaceae). Monographs in Systematic Botany from the Missouri Botanical Garden 92: 1- 694.

Holdridge, L. R. 1967. Life Zone Ecology. Tropical Science Center, San Jose, Costa Rica. 206 pp.

Madison M. 1977. A revision of Monstera (Araceae). Contributions from the Gray Herbarium 207: 3-100.

Zuluaga, A. and K.M. Cameron. 2018. Two new species of Monstera (Araceae: Monsteroideae) with entire leaves from Panama and Costa Rica. Phytotaxa. 334: 1-9. 